\title{
La communication de la commission européenne : d'une rationalité technocratique à une stratégie de mobilisation citoyenne?
}

\section{Françoise Massart-Piérard}

\section{(2) OpenEdition \\ Journals}

Édition électronique

URL : http://journals.openedition.org/communicationorganisation/2329

DOI : 10.4000/communicationorganisation.2329

ISSN : $1775-3546$

Éditeur

Presses universitaires de Bordeaux

Édition imprimée

Date de publication : 1 mai 2000

ISSN : 1168-5549

Référence électronique

Françoise Massart-Piérard, «La communication de la commission européenne : d'une rationalité technocratique à une stratégie de mobilisation citoyenne ? ", Communication et organisation [En ligne], 17 | 2000, mis en ligne le 03 décembre 2012, consulté le 19 avril 2019. URL : http://

journals.openedition.org/communicationorganisation/2329; DOI : 10.4000/

communicationorganisation.2329

Ce document a été généré automatiquement le 19 avril 2019.

(c) Presses universitaires de Bordeaux 


\title{
La communication de la commission européenne: d'une rationalité technocratique à une stratégie de mobilisation citoyenne?
}

\author{
Françoise Massart-Piérard
}

\section{RÉSUMÉS}

Les actions de communication et d'information de la CEE furent largement inspirées par les thèses néo-fonctionnalistes jusqu'aux difficultés de ratification du Traité de Maastricht. Sous la pression de l'opinion publique, les chefs d'État et de gouvernement décidèrent de fonder le processus d'intégration sur des principes nouveaux: subsidiarité, proximité du citoyen, transparence. La «forme » de la politique de communication et d'information de la Commission européenne fut modifiée. Les impératifs de respect des identités nationales et de la diversité régionale ainsi que de renouement avec les citoyens se concrétisent dans des opérations de communication décentralisées, de partenariats avec les États membres et de dialogue avec les milieux concernés. Le bilan de la réorientation opérée reste modeste cependant, le jeu d'ouverture se limitant aux élites.

The EEC's communication and information initiatives were inspired primarily by neofunctionalist ideology until the the Maastricht treaty. Under pressure, heads of state and of the governments of the European Union member states decided to found the integration process on new principles : subsidiarity, proximity of the citizen and transparency. The form of the EC's communication and information policy was modified. The imperatives of the respect of national 
identities and of regional diversity as well as that of reuniting with the citizen were enshrined in decentralized communication initiatives, in partnerships with the member states and in dialogues with the relevant groups. Nevertheless, the success of the change is fairly limited, with the new openness being limited principally to the elites.

INDEX

Mots-clés : Europe, subsidiarite, neo-fonctionnalisme, neo-institutionalisme, transparence, culture administrative

\section{AUTEUR}

\section{FRANÇOISE MASSART-PIÉRARD}

Françoise Massart-Piérard est docteur en sciences politiques de l'Université Catholique de Louvain (Louvain-la-Neuve) où elle dispense les cours de culture politique, analyse des organisations publiques et le séminaire de questions culturelles internationales, notamment. Ses domaines de recherche sont l'intégration européenne, la Francophonie, l'Europe des Régions, la politique extérieure des collectivités décentralisées et des entités fédérées. Elle a publié plusieurs articles et ouvrages consacrés à ces problématiques. 